\title{
A regulatory framework for the art market?
}

Citation for published version (APA):

Bolz, A. K. J. (2019). A regulatory framework for the art market? Authenticity, forgery and the role of art experts. [Doctoral Thesis, Maastricht University]. Maastricht University. https://doi.org/10.26481/dis.20191023ab

Document status and date:

Published: 01/01/2019

DOI:

10.26481/dis.20191023ab

Document Version:

Publisher's PDF, also known as Version of record

\section{Please check the document version of this publication:}

- A submitted manuscript is the version of the article upon submission and before peer-review. There can be important differences between the submitted version and the official published version of record.

People interested in the research are advised to contact the author for the final version of the publication, or visit the DOI to the publisher's website.

- The final author version and the galley proof are versions of the publication after peer review.

- The final published version features the final layout of the paper including the volume, issue and page numbers.

Link to publication

\footnotetext{
General rights rights.

- You may freely distribute the URL identifying the publication in the public portal. please follow below link for the End User Agreement:

www.umlib.nl/taverne-license

Take down policy

If you believe that this document breaches copyright please contact us at:

repository@maastrichtuniversity.nl

providing details and we will investigate your claim.
}

Copyright and moral rights for the publications made accessible in the public portal are retained by the authors and/or other copyright owners and it is a condition of accessing publications that users recognise and abide by the legal requirements associated with these

- Users may download and print one copy of any publication from the public portal for the purpose of private study or research.

- You may not further distribute the material or use it for any profit-making activity or commercial gain

If the publication is distributed under the terms of Article $25 \mathrm{fa}$ of the Dutch Copyright Act, indicated by the "Taverne" license above, 


\section{SAMENVATTING}

De laatste tijd wordt de kunstmarkt geconfronteerd met een verbazingwekkend groot aantal incidenten die samengevat kunnen worden onder de definitie van 'kunstfraude'. Onder kunstfraude wordt in het algemeen verstaan het opzettelijk verkeerd voorstellen van de maker, de leeftijd, de herkomst of de herkomst van een kunstwerk om financieel gewin te behalen. In dit opzicht is namaak misschien wel de bekendste vorm van kunstfraude.

Deze status-quo kan deels worden verklaard door het juridische en historische kader van de kunstmarkt. Gekenmerkt door traditionele en deels archaïsche structuren, heeft de markt weinig gedaan om zijn werking aan te passen aan de economische ontwikkelingen en eisen. Juist op deze gebieden ontbreekt het de kunstmarkt aan algemeen geldende normen en richtlijnen. Daarnaast heeft de markt tal van eigenaardigheden die haar gevoelig maken voor onethisch en illegaal gedrag. De kunstgeschiedenis zit dan ook vol vervalsingen en fraudeurs hebben nog steeds een makkelijke tijd op de kunstmarkt. Historisch beruchte kunstvervalsers als Han van Meegeren of Elmyr de Hory hebben al decennia geleden de aanzienlijke zwaktes in de authenticatieprocedures en vooral in de werkwijze van kunstkenners blootgelegd. Door het aanhoudende gebrek aan gestandaardiseerde expertise wordt ervan uitgegaan dat het foutenpercentage van kunstkenners in deskundigenadviezen boven de 60 procent ligt - een cijfer dat in andere vakgebieden niet geaccepteerd of zelfs getolereerd zou worden. Dit wijst erop dat de bovengenoemde gevallen van vervalsing, met hun aanzienlijke gevolgen, aanleiding hadden moeten geven tot een heroverweging van de heersende structuren en lering hadden moeten trekken uit eerdere mislukkingen. Maar de omvang van de Beltracchi en Knoedler Gallery debacle suggereert dat er niet opnieuw is nagedacht: De kunstmarkt blijft vasthouden aan het monopolie van experts op het gebied van authenticatie en attributie en experts voelen zich niet geneigd om hun werkwijze te standaardiseren om ze op een nauwkeuriger en minder foutgevoelig niveau te brengen.

De schandalen rond de kunstvervalser Wolfgang Beltracchi en de New Yorkse galerie Knoedler hebben het vertrouwen van het publiek in de handel en het expertsysteem geschokt. Zij hebben er ook toe geleid dat de roep om een betere controle en regulering van deze van oudsher ondoorzichtige markt is toegenomen. Daarnaast wordt het beroep van kunstkenner ook van een andere kant aangevallen: Deskundigen worden in toenemende mate aangeklaagd voor vermijdbare valse adviezen, met als gevolg dat sommige deskundigen niet langer oordelen of adviezen geven uit angst voor aansprakelijkheidsgevolgen.

Met betrekking tot de hierboven geschetste ontwikkelingen gaat het proefschrift in op de volgende aspecten: Ten eerste, om de recente ontwikkelingen in de kunstmarkt te analyseren 
die van invloed zijn op het gebied van authenticatie en attributie. De structuren, de marktdeelnemers en de (ontbrekende) methodiek van de markt worden hierboven toegelicht. Aan de hand van de casestudy's kan worden afgeleid dat de bestaande structuren tekortkomingen en zwakke punten vertonen die moeten worden verholpen. De aansprakelijkheid van kunstkenners in verschillende jurisdicties staat centraal in de discussie. Een ander belangrijk aspect zijn de economische anomalieën die de kunstmarkt kenmerken. Daarnaast heeft het feit dat kunst steeds meer als een financieel product wordt gezien, ingrijpende gevolgen voor alle betrokken actoren, met name deskundigen en authenticatieautoriteiten.

De hoofdstukken II en III geven de juridische en feitelijke achtergrond voor de huidige debatten op de kunstmarkt. Het eerste deel van hoofdstuk II richt zich op de structuur en de deelnemers van de kunstmarkt en is bedoeld om de basis te leggen voor de daaropvolgende analyse van de resultaten. Van de meest recente feiten en cijfers tot een analyse van de belangrijkste handelspartners in de markt, bevat dit hoofdstuk ook een aantal casestudy's die aantonen waarom sommige van de handelspraktijken aanleiding geven tot juridische problemen en geschillen. Het tweede deel gaat in detail in op één bijzonderheid: de waardering van kunst. Het behandelt ook de effecten van handel met voorkennis, prijsafspraken en manipulatie op de werking en perceptie van de markt.

Vervolgens wordt in hoofdstuk III ingegaan op de risico's voor de handel als gevolg van deze vervalsingen en authentificatieproblemen. In het eerste deel worden de belangrijkste historische en actuele gevallen van namaak besproken ter illustratie van het theoretische kader. Het tweede deel richt zich op het authenticatieproces, met een focus op de centrale rol van kunstkenners. In deze context worden de verschillende procedures en normen geanalyseerd, met inbegrip van de rol van authenticatieborden en catalogi raisonnés.

Op basis van de bevindingen van de hoofdstukken II en III wordt in hoofdstuk IV uitgelegd waarom de kunstmarkt wordt gekenmerkt door een hoge mate van economische inefficiëntie en hoe dit het succes van regelgevende maatregelen en initiatieven kan beïnvloeden. Met name het huidige regelgevingssysteem op de Amerikaanse kunstmarkt en de regulering van de Australische Aboriginal kunstmarkt dienen als illustratieve casestudies. Ook worden recente initiatieven en de groeiende rol van wetenschap en technologie in deze context geëvalueerd. Ten slotte worden ook andere mogelijke rechtsmiddelen besproken, zoals een titelverzekering, contractuele overwegingen en alternatieve geschillenbeslechting.

Ten laatste worden aanbevelingen gedaan om de bestaande structuur te verbeteren. Dit is geformuleerd in hoofdstuk $\mathrm{V}$, dat de basis moet vormen voor eventuele regelgevende 
maatregelen op basis van de voorbereidende werkzaamheden en het theoretische kader van de eerste hoofdstukken. Op basis van de analyse is dit deel gewijd aan het vertalen van de vastgestelde tekortkomingen in concrete hervormingsvoorstellen. De besproken voorstellen zijn in de eerste plaats gericht aan de stakeholders in het authenticatieproces: elke authenticatiemethode heeft specifieke sterktes en zwaktes, en er wordt geanalyseerd hoe meer gestandaardiseerde standaarden en gecentraliseerde authenticatiemethoden het doel kunnen dienen om risico's en onzekerheden te minimaliseren en de aansprakelijkheidsrisico's van kunstkenners berekenbaarder te maken. 